\title{
Wilson Disease in the South Chinese Han Population
}

\author{
Nan Cheng, Kai Wang, Wenbin Hu, Daoyin Sun, Xun Wang, Jiyuan Hu, \\ Renmin Yang, Yongzhu Han
}

\begin{abstract}
Purpose: To prospectively investigate the incidence and prevalence of Wilson disease (WD) in Chinese Han population in Anhui Province, to analyze the genetic mutations in individuals with WD, and to provide basic epidemiological data regarding WD in this Chinese Han population. Methods: Between November 2008 and June 2010, individuals aged from 7 to 75 years were screened for the cornea K-F ring in both eyes using slit lamp examination and random sampling methods based on age stratification and cluster level 1. The participants were from Anhui Province's Hanshan County, Jinzhai County, and Lixin County. The clinical manifestations of the brain, liver, kidney, skin, and other organs in each individual were also determined. Individuals with positive K-F rings and clinical manifestations indicative of WD underwent copper biochemistry evaluations, abdominal ultrasound testing, and ATP7B gene mutation screening to confirm or exclude the diagnosis of WD. Results: Of 153,370 individuals investigated in this study, nine were diagnosed with WD. In these WD individuals, three cases had neurological symptoms, one has hepatic symptoms, one was hepatic and neurological combined, and the other four cases were presymptomatic. Of the eight individuals in whom genetic mutations were detected, seven individuals had mutations in the $A T P 7 B$ gene. The other individual had no $A T P 7 B$ gene mutations but her copper biochemical test results met the diagnostic criteria for WD. The incidence and prevalence of WD in this population were approximately $1.96 / 100,000$ and 5.87/100,000 respectively. Conclusion: The Chinese Han population had a higher average prevalence of WD than the populations of the United States or Europe.
\end{abstract}

RÉSUMÉ: Maladie de Wilson dans la population chinoise Han du sud. Objectif : Le but de l'étude était d'étudier de façon prospective l'incidence et la prévalence de la maladie de Wilson (MW) dans la population chinoise Han de la province d'Anhui, d'analyser les mutations génétiques chez les individus atteints et de fournir des données épidémiologiques de base concernant la MW dans cette population chinoise Han. Méthode : Nous avons dépisté les anneaux de K-F dans les deux yeux d'individus âgés de 7 à 75 ans entre novembre 2008 et juin 2010 par un examen à la lampe à fente. Les individus étaient choisis par des méthodes d'échantillonnage aléatoire et stratifiés selon l'âge et le degré d'apparentement. Les participants provenaient des comtés d'Hanshan, de Jinzhai et de Lixin dans la province d'Anhui. Les manifestations cliniques au niveau du cerveau, du foie, des reins, de la peau et des autres organes chez chaque individu ont également été déterminées. Les individus qui présentaient des anneaux de K-F et des manifestations cliniques de MW ont subi des évaluations biochimiques du cuivre, une échographie abdominale et un dépistage de mutations du gène ATP7B afin de confirmer ou d'exclure le diagnostic de MW. Résultats : Parmi les 153,370 individus étudiés, neuf ont reçu un diagnostic de MW. Chez ces individus atteints de la MW, trois présentaient des manifestations neurologiques, un présentait des manifestations hépatiques, un présentait des manifestations hépatiques et neurologiques et les quatre autres étaient présymptomatiques. Parmi les 8 individus chez qui des mutations génétiques ont été détectées, 7 avaient des mutations du gène ATP7B. L'autre individu n'avait pas de mutation du gène ATP7B mais ses résultats biochimiques pour le dosage du cuivre rencontraient les critères diagnostiques de la MW. L'incidence et la prévalence de la MW dans cette population étaient approximativement de 1,96 / 100,000 et de 5,7 / 100,000 respectivement. Conclusion : Chez la population chinoise Han, la prévalence moyenne de la MW est plus élevée que celle observée dans la population des États-Unis ou de l'Europe.

Can J Neurol Sci. 2014; 41: 363-367

Wilson disease (WD), also known as hepatolenticular degeneration (HLD), is an autosomal recessive genetic disorder involving disruption of copper metabolism. Wilson disease is caused by mutations in the $A T P 7 B$ gene on chromosome $13 q 14.3$ encoding a P-type copper transporting adenosine triphosphate (ATP) enzyme. The mutations of $A T P 7 B$ gene leads to obstacles in bile excretion of copper in the liver and to obstacles in combination of copper with ceruloplasmin. It also causes the emergence of characteristic biochemical changes, including decreased ceruloplasmin (CP) levels in the serum, increased copper content in the liver, and increased 24-hour urinary copper level. Due to excessive deposition of copper in the liver, brain, kidney, cornea, and other tissues and organs, the main clinical manifestations of WD include cirrhosis of the liver, neurological and/or psychiatric symptoms, and corneal K-F ring ${ }^{1}$.

The incidence of WD is approximately $1.5 / 100,000$ to $3 / 100,000$ and the carrier frequency is approximately $1 / 90^{1-3}$. Hu

From the Hospital Affiliated to Institute of Neurology (NC, WH, DS, XW, JH, RY, YH), Anhui College of TCM; Department of Neurology (KW), The First Affiliated Hospital of Anhui Medical University, Hefei, Anhui, China.

Received April 4, 2013. Final Revisions Submitted November 20, 2013. Correspondence to: Yongzhu Han, Hospital Affiliated to Institute of Neurology, Anhui College of TCM, No. 357 Changjiang Road, Hefei, Anhui, China.

Email: hanyongzhutcm@yahoo.com.cn. 
et al, reported the incidence and prevalence of HLD in the Chinese population based on the results of the epidemiological investigation of 8,758 individuals in Rongqi Town, Shunde City, Guangdong Province ${ }^{4}$. However, so far, no large-sample epidemiological study has been performed on the Chinese population. In the present study, we investigated the incidence and prevalence of WD in Chinese Han individuals using slit lamp examination for corneal K-F ring in both eyes. The study was performed in Hanshan County, Jinzhai County, and Lixin County in Anhui Province between November 2008 and June 2010. To determine the characteristics of gene mutations, the patients with WD identified in this study underwent further detection for the $A T P 7 B$ gene mutations.

\section{Subjects And Methods}

\section{Subjects}

The study population was selected from the foothills between the Yangtze River and the Huaihe River in Anhui Province, including all urban and rural residents in Hanshan County, Jinzhai County, which is located in the Dabie Mountains, and Lixin County, which is located on the plains north of the Huaihe River. As of the end of 2009, the population of Hanshan County was about 490,000, and the combined population of Jinzhai County and Lixin County was about 2,210,000. The geographical regions of China are shown in Figure 1.

\section{Sampling Methods}

Twenty-five schools, 15 factories, 5 communities, 20 administrative organs and units, and 18 villages in the three counties were selected for a sample survey. The following locations in each county were selected. Sites within Hanshan

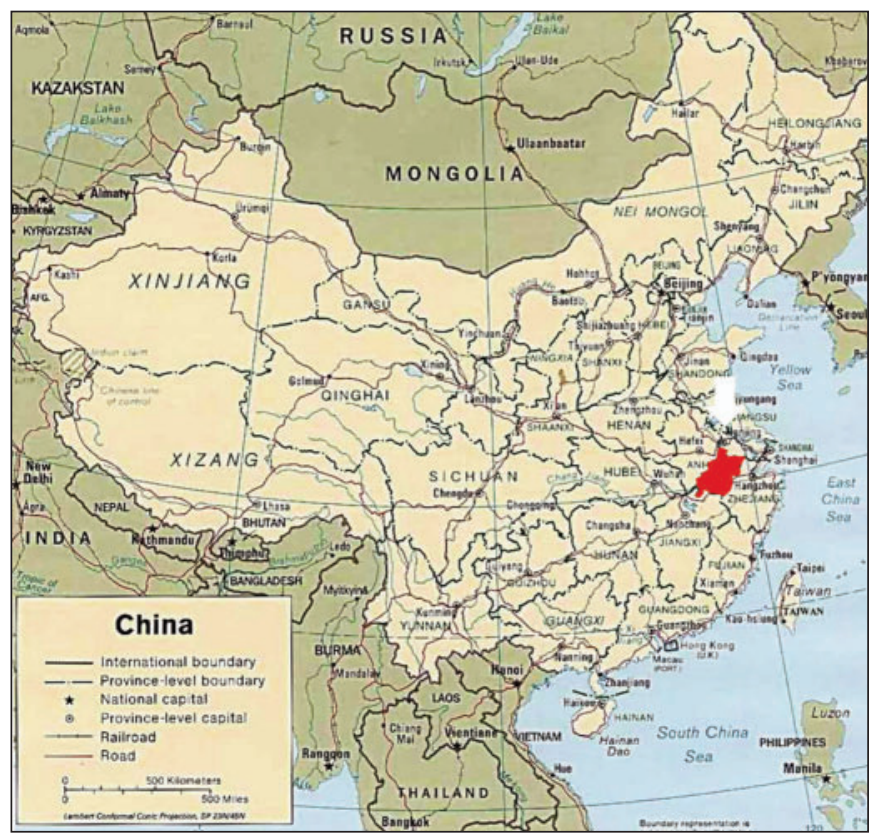

Figure 1: The geographical regions of China.
County included Xianzong, Xieji, Yaomiao, Zhaoguan, Qingxi, Huanfeng, Yuncao, Taochang, and Chengguan Town. Sites within Jinzhai County included Nanxi, Banzhuyuan, Baitafan, Quanjun, Guanmiao, and Meishan Town. Sites within Lixin County included Kantuan, Zhangou, Chengjiaji, Sunmiao, Xinzhangji, Danfeng, and Chengguan Town.

Considering that the corneal K-F ring is uncommon in individuals with WD who are under the age of seven and that many individuals over 75 years of age are frail, have poor mobility, and often have poor compliance, only individuals whose ages were between 7 and 75 years were selected for the WD epidemiological survey.

A two-stage method was used in this survey. In the first stage, using the random sampling methods based on age stratification and cluster level 1, individuals aged from 7 to 75 years were screened by two specialists for the cornea K-F ring in both eyes using slit lamp. The clinical manifestations of the brain, liver, kidney, skin, and other organs in each individual were also determined. During the second stage, individuals with positive $\mathrm{K}-\mathrm{F}$ ring and suspicious WD clinical manifestations were recorded for basic demographic and clinical information, including age of diagnosis, age of onset, gender, occupation, ethnicity, marriage status, family history of nervous system genetic diseases, initial symptoms, and major clinical manifestations. A comprehensive medical examination of the nervous system was performed by two neurologists. To confirm the diagnosis of WD, further blood tests were performed for copper biochemical indices, including serum ceruloplasmin, copper oxidase, and serum copper. B ultrasound scan was performed to detect changes in the liver, gallbladder, spleen, kidney and other organs. Cranial computed tomogram (CT) or magnetic resonance imaging (MRI) testing, penicillamine challenge testing (PCT), and/or liver biopsy were performed as part of the pathological examination. This study was approved by the Ethics Committee of the Hospital Affiliated to Institute of Neurology, Anhui College of TCM.

\section{Diagnostic Criteria of WD}

The diagnostic criteria of WD were based on the Diagnosis and Treatment Guidelines for Hepatolenticular Degeneration developed by the American Association of the Study of Liver Diseases (AASLD) in $2008^{5}$.

\section{Detection of $A T P 7 B$ Gene Mutations}

Genomic DNA was extracted according to the primer sequences reported by Lam et al, the primers of 21 exons and the flanking regions of the $A T P 7 B$ gene were synthesized by Shanghai Invitrogen Biotechnology Co., Ltd. (Invitrogen, U.S. $)^{6,7}$.

The $50 \mu$ polymerase chain reaction (PCR) amplification system consisted of $500 \mathrm{ng}$ genomic DNA, $0.25 \mu \mathrm{M}$ of each primer and $2 \times$ PCR Master Mix (Beijing Solarbio Science \& Technology Co. Ltd.), containing $20 \mathrm{mM}$ Tris- $\mathrm{HCl}, 100 \mathrm{mM}$ $\mathrm{KCl}, 3 \mathrm{mM} \mathrm{MgCl}_{2}, 500 \mu \mathrm{M} \mathrm{dNTP}$, and $0.1 \mathrm{U} / \mu \mathrm{l}$ Taq DNA Polymerase. Polymerase chain reaction amplification reaction conditions were as follows: preheating at $95^{\circ} \mathrm{C}$ for 10 minutes (min), denaturation at $95^{\circ} \mathrm{C}$ for 30 seconds (s), annealing at 63$56^{\circ} \mathrm{C}$ for $45 \mathrm{~s}$ (reduced by $0.5^{\circ} \mathrm{C}$ for each cycle from $63^{\circ} \mathrm{C}$ to $56^{\circ} \mathrm{C}$ ), extension at $72^{\circ} \mathrm{C}$ for $45 \mathrm{~s}$, then 20 cycles with the 
annealing temperature fixed at $56^{\circ} \mathrm{C}$, and a final extension at $72^{\circ} \mathrm{C}$ for $10 \mathrm{~min}$.

Polymerase chain reaction products were purified using an Axygen Purification Kit and sequenced using an ABI 3730 Automated Sequencer by Shanghai Invitrogen Biotechnology Co., Ltd. (Invitrogen). The sequencing results were compared to the human $A T P 7 B$ gene sequence in GenBank (NC-000013) using Omiga software. Samples producing abnormal sequencing results were subjected to bidirectional sequencing. Novel mutations were detected in 52 normal control subjects using sequencing to exclude polymorphism.

\section{RESULTS}

\section{Gender and Age Distribution}

In this study, a total of 153,370 South Chinese Han population from three counties were screened for the corneal K-F ring using slit lamp examination. These included 112,810 individuals from Hanshan County and 40,560 individuals from Jinzhai County and Lixin County. Of these individuals, 72,141 were men or boys and 81,229 were women or girls. Of these, 24,567 individuals were between 7 and 14 years-of-age. Another 44,658 individuals were between 15 and 20 years-of-age, 42,111 individuals were between 21 and 45 years-of-age, 27,134 individuals were between 46 years-of-age and 65 years-of-age, and 14,900 individuals were between 66 years-of-age and 75 years-of-age.

\section{Patients Diagnosed with WD}

Of the 153,370 individuals surveyed in this study, nine individuals were diagnosed with WD. All of them were Han Chinese. There were four males and five female individuals. The onset of WD in these individuals took place during childhood or adolescence. Their parents had all entered into non-kin marriages. Of these nine individuals, eight were positive for the corneal K-F ring and one did not. However, because his sister had been diagnosed with WD, this individual was examined further and diagnosed with WD through examination of his blood copper biochemistry. Of these nine individuals, three cases had neurological symptoms, one has hepatic symptoms, one was hepatic and neurological combined, and the other four cases were presymptomatic. The other four individuals were presymptomatic. Of the five individuals with clinical symptoms, three had a course less than one year, one had a course of five years, and the other had a course of 13 years.

Of these nine individuals, Case 1 and Case 2 were siblings. Case 8 and Case 9 were also siblings. Case 5 had abnormal liver function, including increased bile acids, bilirubin, alanine aminotransferase, and aspartate aminotransferase. Case 5 also had decreased serum albumin levels. Case 5 had four siblings, one whom had died of unexplained liver disease. The son of a cousin of Case 6 had been diagnosed with WD. The other three cases (Cases 3, 4, and 7) were from three independent pedigrees and had no family history of WD or other genetic diseases. Case 3 was married, but the other eight cases were not. Case 7 tested positive for the K-F ring but had no clinical symptoms, normal liver function, and slightly reduced copper biochemistry. The penicillamine challenge test results showed Case 7 to have a 24 hours (h) urinary copper content of $125.44 \mu \mathrm{g}$ before taking Dpenicillamine and a $24 \mathrm{~h}$ urinary copper content of $1732.48 \mu \mathrm{g}$ after administration of $500 \mathrm{mg}$ of D-penicillamine followed by $500 \mathrm{mg}$ of D-penicillamine $12 \mathrm{~h}$ later. Case 7 was diagnosed with WD in this way. The clinical features of the nine individuals with WD are shown in the Table.

Table: Clinical features and genetic testing results of the HLD individuals identified from the epidemiological survey of HLD in Hanshan County, Jinzhai County, and Lixin County in Anhui Province

\begin{tabular}{|c|c|c|c|c|c|c|c|c|c|c|c|c|c|}
\hline No. & Gender & Clinical type & Age & Occupation & $\begin{array}{l}\text { Family } \\
\text { history }\end{array}$ & $\begin{array}{l}\text { Initial } \\
\text { symptoms }\end{array}$ & \begin{tabular}{|l|} 
Serum \\
copper \\
$(\mu \mathrm{mol} / \mathrm{L})$ \\
\end{tabular} & $\begin{array}{l}\text { Copper } \\
\text { oxidase } \\
(\mathrm{OD})\end{array}$ & $\begin{array}{l}\text { Ceruloplasmin } \\
(\mu \mathrm{g} / \mathrm{ml})\end{array}$ & $\begin{array}{l}\text { B ultrasound } \\
\text { scan }\end{array}$ & Head CT/MRI & Genetic abnormalities & $\begin{array}{l}24 \text { hour urine } \\
\text { copper } \\
(\mu \mathrm{g} / 24 \mathrm{~h})\end{array}$ \\
\hline 1 & female & Rigid dystonia & 18 & farmer & yes & $\begin{array}{l}\text { extrapyram } \\
\text { idal } \\
\text { symptoms }\end{array}$ & 42.5 & 0.05 & 145.92 & $\begin{array}{l}\text { Abnormal } \\
\text { liver ultra- } \\
\text { sonography }\end{array}$ & $\begin{array}{l}\text { head MRI: long T1 and long T2 } \\
\text { abnormal signal in bilateral } \\
\text { basal ganglia and thalamus }\end{array}$ & $\begin{array}{l}\text { Arg778Leu/Pro992Leu } \\
\text { compound } \\
\text { heterozygous mutation }\end{array}$ & 166.13 \\
\hline 2 & male & Presymp-tomatic & 17 & student & yes & - & 32.10 & $0 . .02$ & 153.60 & $\begin{array}{l}\text { Abnormal } \\
\text { liver ultra- } \\
\text { sonography }\end{array}$ & & $\begin{array}{l}\text { Arg778Leu/Pro992Leu } \\
\text { compound heterozygous } \\
\text { mutation }\end{array}$ & 206.92 \\
\hline 3 & female & $\begin{array}{l}\text { Movement } \\
\text { disorders }\end{array}$ & 28 & cadre & no & $\begin{array}{l}\text { mental } \\
\text { symptoms }\end{array}$ & 95.90 & 0.03 & 103.04 & $\begin{array}{l}\text { Abnormal } \\
\text { liver ultra- } \\
\text { sonography }\end{array}$ & $\begin{array}{l}\text { head CT: low density signal in } \\
\text { bilateral lenticular nucleus }\end{array}$ & $\begin{array}{l}2731-2 \mathrm{~A}>\mathrm{T} \\
\text { heterozygous mutation }\end{array}$ & 158.80 \\
\hline 4 & male & \begin{tabular}{|l|} 
Resembling \\
autoimmune \\
hepatitisn \\
Movement \\
disorders \\
\end{tabular} & 12 & student & no & $\begin{array}{l}\text { extrapyram } \\
\text { idal } \\
\text { symptoms }\end{array}$ & 43.80 & 0.06 & 360.96 & Fatty liver & $\begin{array}{l}\text { head MRI: long T1 and long T2 } \\
\text { abnormal signal in bilateral } \\
\text { basal ganglia and thalamus }\end{array}$ & $\begin{array}{l}\text { Arg778Leu/Pro992Leu } \\
\text { compound heterozygous } \\
\text { mutation }\end{array}$ & 276.84 \\
\hline 5 & female & \begin{tabular}{|l|} 
elevated serum \\
aminotransferase \\
activity \\
\end{tabular} & 16 & farmer & no & \begin{tabular}{|l} 
liver \\
symptoms
\end{tabular} & 59.90 & 0.03 & 115.20 & Fatty liver & & No mutations & 448.08 \\
\hline 6 & male & presymptomatic & 14 & student & yes & - & 52.20 & 0.05 & 302.72 & Fatty liver & $\begin{array}{l}\text { head CT: no obvious } \\
\text { abnormalities }\end{array}$ & $\begin{array}{l}\text { Arg778Leu/Glu1173Lys } \\
\text { compound heterozygous } \\
\text { mutation }\end{array}$ & 192.39 \\
\hline 7 & male & presymptomatic & 12 & student & yes & - & \begin{tabular}{|l|}
629.76 \\
\end{tabular} & \begin{tabular}{|l|l|}
0.17 \\
\end{tabular} & 189.50 & & & not detected & 125.44 \\
\hline 8 & female & \begin{tabular}{|l|} 
Movement \\
disorders, \\
Acute hepatitis \\
\end{tabular} & 18 & student & yes & $\begin{array}{l}\text { liver } \\
\text { disdase }\end{array}$ & 77.00 & 0.04 & 183.0 & $\begin{array}{l}\text { Fatty liver s, } \\
\text { spleen } \\
\text { removed }\end{array}$ & $\begin{array}{l}\text { head MRI: long T1 and long T2 } \\
\text { abnormal signal in bilateral } \\
\text { basal ganglia and brainstem } \\
\end{array}$ & $\begin{array}{l}\text { Arg778Leu/3061-3C }>\mathrm{A} \\
\text { compound heterozygous } \\
\text { mutation }\end{array}$ & 232.06 \\
\hline 9 & Female & Presymptomatic & 12 & Student & Yes & - & 80.0 & 0.05 & 184.32 & $\begin{array}{l}\text { Abnormal } \\
\text { liver ultra- } \\
\text { sonography }\end{array}$ & $\begin{array}{l}\text { head MRI: no obvious } \\
\text { abnormalities }\end{array}$ & $\begin{array}{l}\text { Arg778Leu/3061-3C }>\mathrm{A} \\
\text { compound heterozygous } \\
\text { mutation }\end{array}$ & 320.24 \\
\hline
\end{tabular}



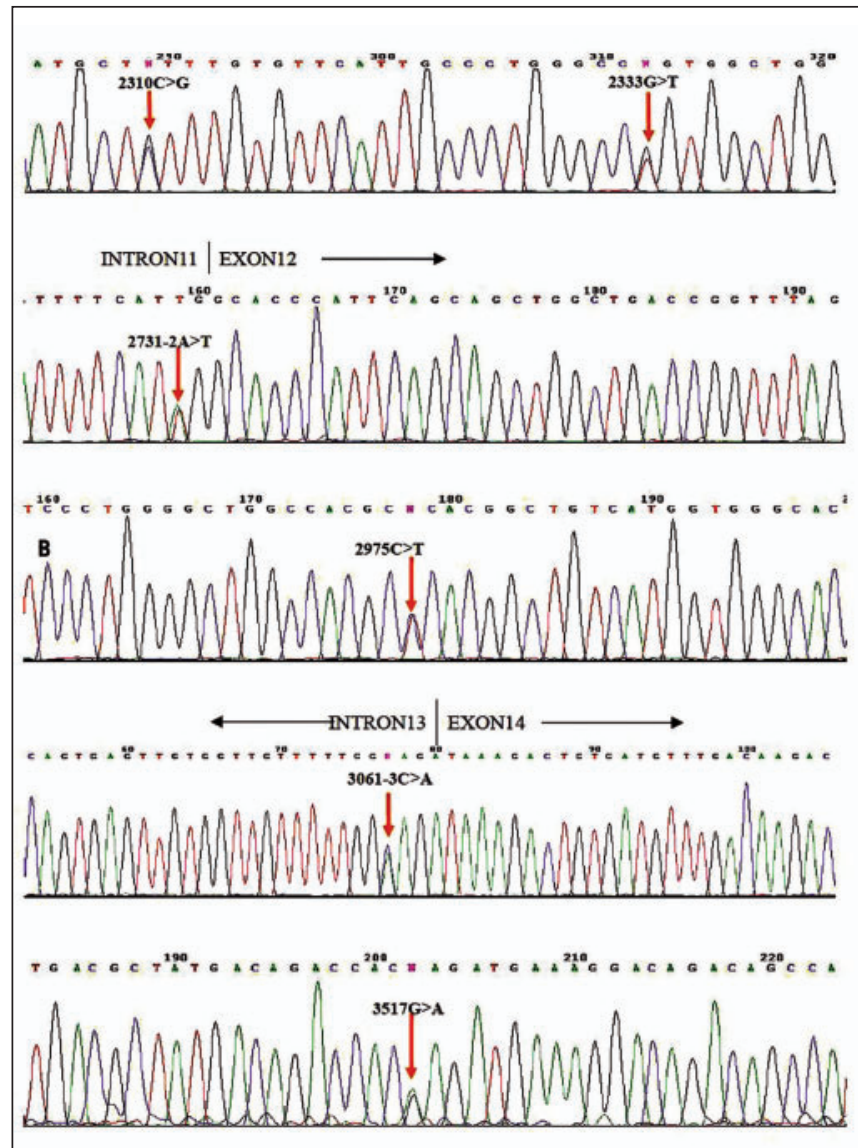

Figure 2: Eight of the nine individuals with WD were screened for ATP7B gene mutations. Of these eight individuals, seven were found to carry six mutations in exons and the promoter region, including Gln511Stop, Arg778Leu, Arg919Gly, Pro992Leu, Ala1018Val, and Arg1041Trp.

\section{Results of Genetic Mutation Testing Results Among Individuals with WD}

In this study, eight of the nine individuals with WD were screened for $A T P 7 B$ gene mutations. Of these eight individuals, seven were found to carry six mutations in exons and the promoter region, including Gln511Stop, Arg778Leu, Arg919Gly, Pro992Leu, Ala1018Val, and Arg1041Trp. No $A T P 7 B$ mutations were identified in the other individual. These mutations were located at exons 8,12 , and 13 . They were either heterozygous mutations or compound heterozygous mutations. The genetic mutation test results of these eight WD individuals are shown in the Table. The sequencing images are shown in Figure 2.

\section{Incidence and Prevalence of WD}

A total of nine HLD patients were identified from among 153,370 individuals, including three patients in which the disease had been active for less than one year. The incidence and prevalence of WD in this population were approximately $1.96 / 100,000$ and 5.87/100,000, respectively.

\section{Discussion}

Wilson disease is one of a small number of treatable genetic diseases affecting the nerves. The condition of the majority of individuals can be controlled so effectively that they can have a nearly normal life expectancy and quality of life if diagnosed early and treated promptly. Otherwise, the prognosis is poor and the condition can even be life-threatening ${ }^{6,7}$. Because of technical and diagnostic limitations, WD is considered a rare disease and has not received much attention ${ }^{8,9}$. In addition, because it is highly clinically and genetically heterogeneous and has complex clinical manifestations during its early stages, this disease is prone to misdiagnosis and missed diagnosis ${ }^{10-12}$. Therefore, epidemiological investigations of the prevalence and incidence of WD in populations are important and may improve the diagnosis and treatment of the disease and avoid misdiagnosis and improper treatment.

Due to differences in geography, ethnicity, and statistical methodology, the results of various epidemiological studies on WD can differ significantly. In epidemiological studies performed in Europe and the United States, the incidence and prevalence of WD have been reported as $0.2 / 100,000$ and $1 / 100,000$ respectively. The heterozygous rate was $1 / 4,000$ and the gene frequency was $0.0056^{13}$. Epidemiological data collected in Japan and South Korea showed that the prevalence of WD was approximately $1.9 / 10,000-6.8 / 100,000$, the heterozygous rate was approximately $6.6 / 1000-13 / 1000$, and the gene frequency was $0.0055^{14,15}$. Loudianos et al reported that the incidence of WD in the Sardinian island population was approximately $1 / 7000$ newborns ${ }^{16}$. However, another study showed the incidence of WD in the Crete population in Greece to be up to $6 / 90$ newborns ${ }^{17}$. Wilson disease is not reported to occur in newborns. It is rarely found in those less than two years old.

Epidemiological data regarding WD in Chinese populations remains limited. A study of individuals attending the nerve hereditary disease specialist clinic in the First Affiliated Hospital of Zhongshan Medical University from 1982 to 1991 showed WD to account for $10.14 \%$ of all the individuals, making it the second most common disease among all monogenic diseases ${ }^{18}$. In 1996, Hu and colleagues identified one WD individual from an epidemiological survey of 8,758 individuals in Rongqi Town, Shunde City, Guangdong Province ${ }^{4}$. However, so far, no largesample WD epidemiological study has been performed in any Chinese population.

In this study, an epidemiological survey was performed on the Chinese Han population in Hanshan County, Jinzhai County, and Lixin County in Anhui Province. The incidence and prevalence of WD were about 1.96/10,000 and 5.87/100,000, respectively. Our results are consistent with the results from similar studies in Japan and South Korea but they report significantly higher values than studies performed in the United States and Europe. This difference may be due to racial differences between Asian and Caucasian populations.

Together with the findings of other studies performed in Chinese Han populations, our findings suggest that the mutation frequency is higher in exons 8,12 , and 13 than at other sites in the $A T P 7 B$ gene and that these sites may be mutation hotspots in the Chinese Han population ${ }^{19,20}$. As confirmed by DNA sequencing, six individuals in our study were found to have the Arg778Leu mutation in exon 8, three individuals had the 
Pro992Leu mutation in exon 13, and two individuals had the 3061-3C> A heterozygous mutation in exon 14, which has been reported in the HLD individuals from Hong Kong and Macao ${ }^{21}$. Mutations in exons 12 and 16 were each detected in a single individual. Because the blood samples were collected from one case, we did not test the $A T P 7 B$ gene in this patient and further genetic testing as a tool both to confirm the diagnosis of WD and for WD screening is warranted. In our study, all genetic mutations were heterozygous mutations. Epigenetics research is necessary in the future.

This study suggests that WD is not a rare disease in the Chinese Han population. Clinicians, particularly neurologists, should increase their vigilance where this disease is concerned during routine clinical diagnosis and treatment. This would facilitate early detection, early diagnosis, and early treatment and reduce the rate of missed diagnosis, misdiagnosis, and improper treatment. This would, in turn, fundamentally improve the prognosis and quality of life of the WD individuals.

In recent years, a variety of fast, high-throughput, highsensitivity detection technologies have emerged. Many of these have been molecular biology techniques that have facilitated a number of large population studies. These studies have shown that the incidence of WD is largely underestimated. Danks reported that 1/3000 newborns had abnormal copies of the WD gene $^{22}$. John estimated that the WD heterozygous population can be as high as $2 \%{ }^{23}$. Ohura et al detected two WD individuals in 2,789 Japanese children between the ages of one and six by testing for ceruloplasmin in dried blood spots using an enzymelinked immunosorbent assay (ELISA) ${ }^{24}$. Using a similar approach, Hahn detected one WD individual in 3,667 Korean children of three months to 15 -year-old ${ }^{25}$. Mak et al detected three p.R778L carriers in 660 unrelated Hong Kong Chinese subjects, estimating the incidence rate to be $1 / 5,400^{21}$. Mak's results suggested that WD is the most common genetic disease involving the liver and nervous system in East $\mathrm{Asia}^{26}$.

Because this study was limited to a single region within Anhui Province, our results do not yet adequately reflect the actual situation of the WD morbidity in the Chinese Han population. Based on the current status of WD epidemiological studies, we will cooperate with other research groups in China to conduct a larger-sample-size, multi-center WD epidemiological study using a variety of high-throughput and high-sensitivity detection technologies.

\section{REFERENCES}

1. Ala A, Walker AP, Ashkan K, et al. Wilson's disease. Lancet. 2007; 369:397-408

2. Badenas Orquin C. Advances in the molecular diagnosis of Wilson's disease. Gastroenterol Hepatol. 2011;34(6):428-33.

3. Scheinberg I, Sternlieb I. Wilson's disease. Major Probl Intern Med. 1984;23:1-24.

4. Jang W, Cho J, Kim JS, et al. Wilson's disease only presenting with isolated unilateral resting tremor. Can J Neurol Sci. 2011;38: 939-40.

5. Roberts EA, Schilsky ML. Diagnosis and treatment of Wilson disease: an update. Hepatology. 2008; 47(6):2089-111.

6. Lee JY, Kim YH, Kim TW, et al. New novel mutation of the ATP7B gene in a family with Wilson disease. J Neurol Sci. 2012;313(12):129-31.

7. Sinha S, Christopher R, Arunodaya GR, et al. Is low serum tocopherol in Wilson's disease a significant symptom? J Neurol Sci. 2005;228:121-3.
8. Lam CW, Mak CM. Allele dropout in PCR-based diagnosis of Wilson disease: mechanisms and solutions. Clin Chemistry. 2006;52:517-20

9. Mak CM, Lam CW. Diagnosis of Wilson's disease: a comprehensive review. Crit Rev Clin Lab Sci. 2008;45(3): 263-90.

10. Chu EC, Chu NS, Huang CC. Autonomic involvement in Wilson's disease: a study of sympathetic skin response and RR interval variation. J Neurol Sci. 1997;149(2):131-7.

11. Li K, Zhang WM, Lin S, et al. Mutational analysis of ATP7B in north Chinese patients with Wilson disease. J Hum Genet. 2012 Dec 13. doi: 10.1038/jhg.2012.134.

12. Sinha S, Christopher R, Arunodaya GR, et al. Is low serum tocopherol in Wilson's disease a significant symptom? J Neurol Sci. 2005;228(2):121-3.

13. Danks DM. Disorders of copper transport. In: Scriver CR, Beaudet AL, Sly WM, Valle D, editors. The metabolic and molecular basis of inherited disease. New York: McGraw Hill; 1995. p. 2211-35.

14. Saito T. An assessment of efficiency in potential screening for Wilson's disease. J Epidemiol Community Health. 1981;35: 27480 .

15. Seo JK. Wilson disease: an update. Korean J Hepatol. 2006;12(3): 333-63.

16. Loudianos G, Dessi V, Lovicu M, et al. Molecular characterization of Wilson disease in the Sardinian population-evidence of a founder effect. Hum Mutat. 1999;14:294-303.

17. Dedoussis GV, Genschel J, Sialvera TE, et al. Wilson disease: high prevalence in a mountainous area of Crete. Ann Hum Genet. 2005;69: 268-74

18. Li X, Liang X, Liu D, et al. Case analysis of 957 individuals with neurological genetic disease. Zhonghua Yi Xue Yi Chuan Xue Za Zhi. 1994;11(6):372-4

19. Xu Y, Fan Y, Yu L, et al. Identification of a mutation hotspot in exon 8 of the Wilson disease gene using PCR direct sequencing. Zhonghua Yi Xue Yi Chuan Xue Za Zhi. 1998;15(5):284-7.

20. Cheng N, Lu B, Du Y, et al. Rapid detection of the mutation hotspots in the Wilson disease gene in Chinese individuals. Zhong Feng Yu Shen Jing Ji Bing Za Zhi. 2009;26(4):414-17.

21. Mak CM, Lam CW, Tam S, et al. Mutational analysis of 65 Wilson disease individuals in Hong Kong Chinese: identification of 17 novel mutations and its genetic heterogeneity. J Hum Genet. 2008;53:55-63.

22. Johnson S. Is Parkinson's disease the heterozygoto form of Wilson's disease: $\mathrm{PD}=1 / 2$ WD? Med Hypotheses. 2001;56(2): 171-3.

23. Ohura T, Abukawa D, Shiraishi H, et al. Pilot study of screening for Wilson disease using dried blood spots obtained from children seen at outindividual clinics. J Inherit Metab Dis. 1999;22: 74-80.

24. Hahn SH, Lee SY, Jang YJ, et al. Pilot study of mass screening for Wilson's disease in Korea. Mol Genet Metab. 2002;76:133-6.

25. Scheinberg I, Sternlieb I. Wilson's disease. Major Probl Intern Med. 1984;23:1-24.

26. Litwin T, Gromadzka G, Członkowska A. Gender differences in Wilson's disease. J Neurol Sci. 2012;312(1-2):31-5. 